\title{
Pelatihan Membangun Komunikasi Artifaktual Pada Siswa SMA
}

\author{
Roswita Oktavianti*, Septia Winduwati, Lydia Irena
}

Fakultas Ilmu Komunikasi Universitas Tarumanagara, Jakarta, Indonesia.

\section{Article history}

Received: 30-05-2020

Revised: 26-06-2020

Accepted: 07-07-2020

*Corresponding Author:

Roswita Oktavianti, Fakultas Ilmu Komunikasi Universitas Tarumanagara, Jakarta, Indonesia

Email:

roswitao@fikom.untar.ac.id

\begin{abstract}
Artifactual communication is a kind of non-verbal communications. The message of artifactual is revealed through physical appearance such as attire and cosmetics. Both of them can create physical attractiveness, self-image and individual personality. Adolescent often have difficulty in accepting their physical bodychanges though some of them are satisfied with their body. In this case, senior high-schools have a social and moral responsibility in order to observe their students who are in adolescence by adjusting the eduction in the class. The team of community service of Faculty of Communication of Universitas Tarumanagara along with SMAN 2 West Jakarta provided a training about the importance of artifactual communications as a kind of non-verbal communications. The aim of this event is to increase the student's understanding, especially young women, about the importance of artifactual messages through facial appearance. It will helps student increasing their confidence. Based on data gathering by questionnaire, it shows that students recognize, have knowledge and understanding, as well as able to identify objects of artifactual communication. Further, giving material along with practical method are effective way to provide understanding in terms of artifactual communications.
\end{abstract}

Keywords: artifactual; communication; non-verbal; adolescent; women

Abtrak: Komunikasi artifaktual merupakan salah satu bentuk komunikasi nonverbal. Pesan artifaktual ini diungkapkan melalui penampilan fisik seseorang seperti pakaian, dan kosmetik. Pakaian dan kosmetik yang dikenakan seseorang mampu menciptakan daya tarik fisik dan memunculkan citra diri serta kepribadian seseorang. Remaja kerap mengalami kesulitan dalam menerima perubahan fisik tubuhnya. Hanya sedikit remaja yang puas dengan tubuhnya. Dalam hal ini, sekolah memiliki tanggungjawab moral dan sosial untuk mengamati perkembangan para siswanya yang berada pada masa remaja dengan cara menyesuaikan pendidikan dengan perkembangan tersebut. Tim pengabdian kepada masyarakat Fakultas Ilmu Komunikasi Universitas Tarumanagara dengan mitra SMA Negeri 2 Jakarta Barat memberikan pemahaman dan pelatihan tentang pentingnya komunikasi artifaktual sebagai salah satu bentuk komunikasi non-verbal. Tujuannya untuk meningkatkan pemahaman remaja khususnya remaja putri tentang pentingnya pesan artifaktual melalui penampilan wajah, untuk membantu meningkatkan kepercayaan diri remaja. Dari hasil kuesioner yang dibagikan setelah kegiatan, menunjukkan bahwa siswa mengenali, memiliki pemahaman, dan mampu mengidentifikasi obyek komunikasi artifaktual. Pemberian materi disertai praktik langsung juga merupakan cara efektif dalam memberikan pemahaman tentang komunikasi artifaktual.

Kata Kunci: artifaktual; komunikasi; non-verbal; masa remaja; wanita 


\section{PENDAHULUAN}

Masa remaja merupakan masa peralihan dari masa anak-anak menuju dewasa. Pada masa ini para remaja kerap mengalami kesulitan dalam menerima perubahan-perubahan fisiknya. Hanya sedikit remaja yang merasa puas dengan tubuhnya. Hal ini disebabkan pertumbuhan tubuhnya dipandang kurang serasi (Fatimah, 2008). Menurut The American School Counselor (Association ASCA), perkembangan remaja terdiri atas tiga tahap yaitu: remaja awal usia 12-14 tahun, remaja pertengahan usia 15-16 tahun, remaja akhir usia 17-19 tahun. Proses ini berlangsung selama tujuh tahun (Sarwono, 2013). Hall menyatakan, pada masa ini banyak masalah yang dihadapi karena remaja berupaya menemukan jati diri atau identitasnya, dalam arti kebutuhan aktualisasi diri (Fatimah, 2008).

Penelitian yang dilakukan Nastiti \& Purworini, menyebutkan bahwa pada dasarnya seorang remaja ingin diakui keberadaannya di hadapan orang lain. Remaja berusaha menampilkan diri secara luas dan mendalam dengan menunjukkan citra positif dalam diri mereka. Penelitian ini menemukan bahwa remaja yang melakukan presentasi diri berusaha membangun konsep diri. Remaja kemudian memperluas konsep diri untuk mendapatkan umpan balik dari orang lain dengan maksud menciptakan harga diri. Jadi, tujuan remaja melakukan presentasi diri adalah untuk menciptakan kembali harga diri mereka di depan publik. Namun penelitian ini hanya mencakup perilaku presentasi diri pada media sosial Instagram atau online, tidak sampai pada perilaku presentasi diri secara offline (Nastiti \& Purworini, 2018).

Penampilan fisik merupakan salah satu perilaku presentasi diri secara offline. Penampilan fisik sangat penting untuk mengenali kepribadian. Penampilan fisik meliputi postur tubuh, tinggi badan, kebersihan dan raut wajah, pakaian yang dikenakan, yang semuanya itu menggambarkan kepribadian seseorang (Sarwono, 2013). Ilmu tentang wajah atau physiognomi berusaha memahami kepribadian atas dasar keadaan wajah. Pengetahuan ini meyakini bahwa terdapat hubungan antara keadaan wajah dan kepribadian. Hal-hal yang tampak pada wajah dapat dipergunakan untuk membuat interpretasi mengenai apa yang terkandung dalam jiwa (Suryabrata, 2016).

Setiap orang memiliki persepsi mengenai penampilan fisik seseorang, baik dari sisi pakaian yang dikenakan (model, kualitas bahan, warna), dan ornamen lain. Karakteristik fisik seperti daya tarik, warna kulit, rambut, kumis, jenggot dan lipstik dapat mengkomunikasikan sesuatu. Studi menunjukkan bahwa daya tarik fisik merupakan ciri penting dalam teori kepribadian meski bersifat implisit. Orang yang menarik secara fisik dinilai lebih pandai bergaul, luwes tenang, menarik, hangat secara seksual, reponsif, persuasif dan berhasil dalam karier daripada orang yang tidak menarik. Bentuk penghargaan terhadap penampilan fisik seseorang berbeda-beda di tiap negara. Di Amerika, orang menghargai wanita yang tinggi dan ramping. Di Jepang, wanita dengan postur tubuh kecil justru paling menarik. Di China, kecantikan wanita diasosiasikan dengan gaya rambut sederhana dengan selendang warna warni, perhiasan atau make up (Mulyana, 2013).

Menurut Duncan, penampilan fisik merupakan salah satu bentuk komunikasi non-verbal (Rakhmat, 2005). Komunikasi nonverbal adalah komunikasi tanpa kata-kata seperti memberi isyarat, tersenyum atau mengerutkan kening, memperlebar mata, menggerakkan kursi, mengenakan perhiasan, menyentuh seseorang, menaikkan volume suara, atau bahkan saat tidak mengatakan apa-apa (DeVito, 2013).

Pesan non-verbal sangat berpengaruh dalam komunikasi. Pesan non-verbal adalah semua isyarat yang bukan kata-kata. Menurut Mark L. Knapp, istilah non-verbal biasanya digunakan untuk melukiskan semua peristiwa komunikasi di luar kata-kata terucap dan tertulis. Richard E. Porter 
membagi pesan- non-verbal menjadi dua kategori besar yakni pertama, perilaku yang terdiri dari penampilan dan pakaian, gerakan dan postur tubuh, ekspresi wajah kontak mata, sentuhan, bau-bauan, dan parabahasa. Kedua, ruang, waktu dan diam (Mulyana, 2013). Terdapat enam jenis pesan nonverbal yakni kinesik atau gerak tubuh, paralinguistik atau suara, proksemik atau penggunaan ruangan personal dan sosial, olfaksi atau penciuman, sensitivitas kulit, dan faktor artifaktual seperti pakaian dan kosmetik (Rakhmat, 2005).

Pesan artifaktual diungkapkan melalui penampilan tubuh seperti pakaian, dan kosmetik. Walaupun bentuk tubuh relatif menetap, orang sering berperilaku dalam hubungan dengan orang lain sesuai dengan persepsinya tentang tubuhnya. Manusia membentuk citra tubuh dengan pakaian dan kosmetik. Kosmetik seperti dinyataan oleh M.S. Wetmore Cosmetic Studio di Encino California dapat mengungkapkan kesehatan (dengan menggunakan base make up untuk meratakan noda kulit), sikap yang ekspresif dan komunikatif (dengan memoles mata), dan kehangatan (dengan mengatur warna bibir). Dalam hal ini kosmetik digunakan untuk menyampaikan identitas (Rakhmat, 2005).

Kegiatan pengabdian kepada masyarakat ini fokus memberi pemahaman dan pelatihan kepada remaja tentang komunikasi artifaktual sebagai salah satu bentuk komunikasi non verbal. Pemahaman tentang komunikasi artifaktual ini dirasa perlu agar para remaja mampu menemukan jati diri dan kepercayaan diri secara tidak berlebihan.

Usaha penemuan jati diri remaja dan upaya mengaktualisasi diri dengan baik dilakukan dengan berbagai pendekatan. Sekolah memiliki tanggungjawab moral dan sosial secara luas dan kompleks. Pendidikan modern menuntut guru mengamati perkembangan penyesuaian diri murid serta mampu menyusun sistem pendidikan yang sesuai dengan perkembangan tersebut. Dengan demikian proses pendidikan merupakan penciptaan penyesuaian antara individu dengan nilai-nilai yang diharuskan oleh lingkungan menurut kepentingan perkembangan individu (Fatimah, 2008).

SMA Negeri 2 Jakarta Barat memiliki program ekstrakurikuler modern dance. Kegiatan ini melibatkan sejumlah remaja putri yang dituntut memiliki penampilan menarik ketika tampil di panggung. Sejauh ini, para siswa memiliki pemahaman tentang make up atau kosmetik tanpa dibarengi dengan pemahaman tentang pesan artifaktual. Tim pengabdian kepada masyarakat Fakultas Ilmu Komunikasi Universitas Tarumanagara turut membantu memberikan pemahaman dan pelatihan tentang komunikasi artifaktual sebagai salah satu bentuk komunikasi non-verbal.

Tujuan dari kegiatan ini untuk meningkatkan pemahaman remaja khususnya remaja putri tentang pentingnya pesan artifaktual melalui penampilan wajah. Hal ini untuk membantu meningkatkan kepercayaan diri remaja. Kepercayaan diri adalah sikap positif seorang individu ang memampukan dirinya untuk mengembangka penilaian positif baik terhadap diri sendiri maupun terhadap lingkungan/situasi yang dihadapinya (Fatimah, 2008).

\section{METODE}

Pada tahap persiapan, tim pengabdian kepada masyarakat mencari SMA dengan radius $<200$ km dari Universitas Tarumanagara yang terletak di Jalan S. Parman No.1 Grogol, Jakarta Barat. Tim pengabdi memilih SMA Negeri 2 di Jalan Gajah Mada No. 175 Keagungan Tamansari RT.1/RW.5 RT.1 4 5, RT.1/RW.5, Keagungan, Kec. Taman Sari, Kota Jakarta Barat, Daerah Khusus Ibukota Jakarta 11130 atau berjarak $\pm 5,1 \mathrm{~km}$ dari Universitas Tarumanagara. SMA Negeri 2 Jakarta Barat didirikan pada tahun 1959. Tim pengabdian kepada masyarakat mengidentifikasi masalah yang tengah dihadapi siswa SMA di ibukota, dan kebutuhan akan adanya pemberian pemahaman dan praktik yang 
tepat. Setelah masalah dipetakan, kegiatan difokuskan pada anggota ekstrakurikuler Modern Dance. Kegiatan pemberian pemahaman tentang komunikasi artifaktual dilaksanakan pada Selasa, 27 Agustus 2019.

Tahap pelaksanaan pelatihan dilakukan dengan, pemberian materi/teori dan praktik. Pertama, pelatihan berupa pemberian materi dilakukan dengan memberikan pengetahuan tentang komunikasi non-verbal dan pesan artifaktual didalamnya berupa penampilan fisik, disertai contoh kasus dan diskusi interaktif. Hal ini agar memudahkan para siswa dalam memahami informasi yang diberikan. Tim pengabdian kepada masyarakat juga melibatkan mahasiswa untuk berbagi pengalaman mengenai komunikasi artifaktual. Kedua, pelatihan berupa praktik. Salah satu siswa ditunjuk sebagai model, lalu dilakukan praktik langsung menciptakan daya tarik fisik secara tidak berlebihan/sewajarnya. Praktik berpenampilan yang baik (bagi siswi) dan menggunakan kosmetik atau make-up sehari-hari secara tidak berlebihan atau natural (bagi siswi).

Pada tahap evaluasi, tim mengedarkan kuisioner sebelum dan setelah kegiatan pengabdian untuk mengetahui sejauhmana pemahaman para siswa tentang komunikasi artifaktual.

\section{HASIL DAN PEMBAHASAN}

\section{Pemahaman Komunikasi Artifaktual}

Para siswi yang tergabung dalam Modern Dance menjadi peserta kegiatan pengabdian kepada masyarakat. Sebanyak 20 siswi mengikuti kegiatan ini. Sebelum pemberian materi dimulai, para siswa diminta mengisi kuisioner untuk mengukur pemahaman yang sudah para siswa miliki terkait komunikasi artifaktual.

Selanjutnya tim pengabdian kepada masyarakat menyampaikan materi secara interaktif, dengan bahasa dan contoh agar mudah dicerna oleh para siswi. Pada kesempatan tersebut, disampaikan garis besar tentang komunikasi artifaktual sebagai jenis komunikasi non-verbal (tanpa kata-kata). Komunikasi non-verbal itu sendiri terdiri atas gerakan tubuh, penampilan, komunikasi wajah, komunikasi mata, komunikasi sentuhan, kecepatan dan volume suara, dan komunikasi artifaktual.

Selanjutnya penjelasan fokus pada komunikasi artifaktual. Pesan artifaktual disampaikan melalui pakaian, perhiasan/aksesoris, rambut, kosmetik/make-up dan perawatan tubuh, warna, hingga wangi tubuh. Masing-masing pesan artifaktual tersebut diberi contoh secara riil dalam kehidupan sehari-hari agar mudah dipahami oleh para siswi.

Setelah diberikan materi tentang komunikasi artifaktual, mahasiswa yang ikut serta dalam kegiatan ini membantu memberikan praktik membangun komunikasi artifaktual melalui penggunaan kosmetika dasar atau make-up dan sejumlah informasi tentang perawatan wajah.

Kosmetika dasar atau kosmetika sederhana antara lain: pelembab atau skincare untuk mengontrol minyak pada wajah (toner, lotion, moisturizer, dll); sunscreen untuk melindungi kulit wajah dari paparan sinar matahari; bedak; pemulas bibir; corrector atau concealer untuk menutupi kekurangan pada wajah; dll (Detikcom, 2020). Salah satu siswi diminta untuk menjadi model. 
Pemahaman tentang Komunikasi Artifaktual Sebelum dan Setelah Pelatihan

Tabel 1 Pemahaman Komunikasi Artifaktual Sebelum dan Setelah Pelatihan

\begin{tabular}{lccccc}
\hline & \multicolumn{2}{c}{ Sebelum (\%) } & \multicolumn{2}{c}{ Setelah (\%) } \\
& Ya & Tidak & Ya & Tidak \\
\hline Mendengar kata "komunikasi artifaktual" & 6 & 94 & 100 & 0 \\
Memahami arti dari "komunikasi artifaktual" & 6 & 94 & 100 & 0 \\
Mengidentifikasi obyek "komunikasi artifaktual" & 6 & 94 & 100 & 0 \\
\hline & \multicolumn{3}{c}{$\mathbf{1 0 0}$} & & $\mathbf{1 0 0}$ \\
\hline
\end{tabular}

Tabel 1 menunjukkan perubahan sebelum dan setelah kegiatan pengabdian kepada masyarakat. Sebelum kegiatan, hanya $6 \%$ siswi pernah mendengar kata "komunikasi artifaktual", memahami arti dari "komunikasi artifaktual" dan mampu mengidentifikasi obyek-obyek komunikasi artifaktual. Sementara, 94\% belum pernah mendengar kata "komunikasi artifaktual, belum memahami arti dari "komunikasi artifaktual, dan belum mengetahui obyek dari komunikasi artifaktual.

Setelah kegiatan, seluruh siswa atau 100\%, menyatakan pernah mendengar kata "komunikasi artifaktual", memahami arti dari "komunikasi artifaktual", dan mampu mengidentifikasi obyek-obyek dari komunikasi artifaktual. Hal ini karena tim pengabdi telah memberikan materi tentang "komunikasi artifaktual" dan memaparkan obyek-obyek buatan tangan manusia yang merupakan bentuk komunikasi artifaktual.

Tabel 2 Penggunaan Kosmetika Dasar (Basic Make-up)

\begin{tabular}{lclc}
\hline & \% & \multicolumn{1}{c}{ Alasan } & \% \\
\hline Ya & 44 & Melindungi wajah dari cuaca & 55 \\
& & Membuat lebih menarik & 27 \\
& & Menutupi kekurangan fisik & 18 \\
Tidak & & & $\mathbf{1 0 0}$ \\
& & & 35 \\
& & Tidak ada waktu & 30 \\
& & Tidak tahu cara menggunakannya & 15 \\
& & Tidak memiliki peralatan/perlengkapan & 15 \\
& & Tidak nyaman & 5 \\
& & & $\mathbf{1 0 0}$ \\
\hline
\end{tabular}

Tabel 2 menunjukkan bahwa 56\% siswa tidak menggunakan kosmetika dasar (basic make-up) ke sekolah, dan 44\% menggunakan kosmetika dasar. Kosmetika dasar meliputi: pelembab atau skincare untuk mengontrol minyak pada wajah; sunscreen untuk melindungi kulit wajah dari paparan sinar matahari; bedak; pemulas bibir; corrector atau concealer untuk menutupi kekurangan pada wajah.

Alasan siswi menggunakan kosmetika dasar ke sekolah yakni untuk melindungi wajah dari cuaca (55\%), agar lebih menarik (27\%), dan untuk menutupi kekurangan fisik (18\%).

Alasan siswi tidak menggunakan kosmetika dasar ke sekolah yakni tidak ada waktu (35\%), tidak tahu cara menggunakannya (30\%), tidak memiliki peralatan/perlengkapan $(15 \%)$, tidak nyaman $(15 \%)$, tidak diizinkan orangtua dan/atau guru $(5 \%)$.

Tabel 3 Mampu Menggunakan Kosmetika Dasar (Basic Make-up)

\begin{tabular}{lc}
\hline Mampu menggunakan & \% \\
\hline Bisa & 60 \\
Ragu ragu & 40 \\
Tidak Bisa & 0 \\
\hline & $\mathbf{1 0 0}$ \\
\hline
\end{tabular}


Tabel 3 menunjukkan bahwa setelah pelatihan komunikasi artifaktual sebanyak $60 \%$ siswi mengetahui cara menggunakan kosmetika dasar, sebanyak 40\% siswi ragu-ragu dengan kemampuannya menggunakan kosmetika dasar, dan $0 \%$ atau tidak ada siswi yang tidak memahami cara menggunakan kosmetika dasar. Hal ini karena, tim pengabdian memberikan pemahaman disertai dengan praktik langsung.
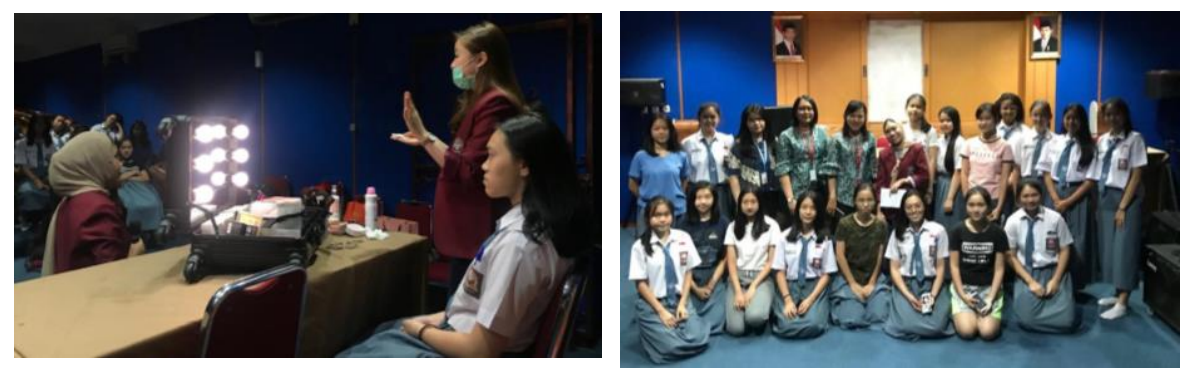

Gambar 1 Tim pengabdian kepada masyarakat Universitas Tarumanagara melakukan praktik menciptakan pesan artifaktual melalui penggunaan kosmetik dan perawatan wajah kepada para siswi SMAN 2 Jakarta Barat

\section{Pembahasan Hasil Kegiatan}

Komunikasi artifaktual terdiri atas pesan yang disampaikan oleh obyek yang dibuat oleh tangan manusia. Dengan demikian, estetika, warna, pakaian, perhiasan, dan gaya rambut, serta keharuman seperti parfum, cologne seluruhnya dipertimbangkan sebagai artifaktual (DeVito, 2013).

Dari hasil kuesioner, komunikasi artifaktual belum familiar/populer di telinga para siswi SMA. Kegiatan pengabdian kepada masyarakat, memberikan pemahaman komunikasi artifaktual secara menyeluruh. Para siswa yang sebelumnya belum pernah mendengar, memahami, dan mengidentifikasi obyek komunikasi artifaktual, telah memperoleh pemahaman yang menyeluruh tentang salah satu jenis komunikasi non-verbal ini. Hal ini dibuktikan dari hasil kuisioner yang menunjukkan seluruh siswa mendengar, memahami, dan mampu mengidentifikasi obyek komunikasi artifaktual secara tepat. Ini menunjukkan bahwa konsep "komunikasi artifaktual" belum akrab di telinga para siswa. Dari hasil diskusi dengan Wakil Kepala Sekolah Bidang Humas Sarana dan Prasarana SMAN 2 Jakarta, Masytoh, pemahaman dan kegiatan tentang komunikasi artifaktual belum pernah diberikan kepada siswa-siswi. Sementara, para siswi kerap membutuhkan keterampilan tersebut pada saat tampil dalam kegiatan baik di dalam maupun di luar sekolah. Kegiatan pengabdian kepada masyarakat berupa pemberian materi singkat dan interaktif, dengan bahasa dan contoh yang mudah dipahami, mampu memberi pemahaman kepada siswa mengenai konsep komunikasi artifaktual dan mengapa perlu diperhatikan untuk membangun kepercayaan diri remaja.

Selanjutnya, tim pengabdian kepada masyarakat memberikan praktik langsung menggunakan kosmetika dasar disertai penjelasan tentang perawatan wajah (personal-hygiene). Praktik menggunakan kosmetika dasar ini dilakukan dari penelitian di bidang pupilometrics. Penelitian ini menunjukkan bahwa pelebaran pupil (pupil dilatasi) atau seseorang yang memiliki pupil yang lebar/besar dinilai lebih menarik daripada yang memiliki pupil kecil. Dalam sebuah foto/lukisan, perempuan yang memiliki pupil lebar dinilai lebih feminin dan lembut. Sebaliknya, perempuan yang memiliki pupil kecil dinilai dingin, keras, dan egois. Inilah yang kemudian membuat industri kosmetik menyediakan berbagai kosmetik khusus mata seperti eye-shadow, eyeliner, bulu mata palsu, dan lensa kontak warna (DeVito, 2013).

Sebagian siswi tidak menggunakan kosmetika dasar ketika ke sekolah termasuk perawatan berupa perlindungan kulit dari paparan cahaya matahari dan polusi. Hal ini karena belum adanya sosialisasi dari pihak sekolah melalui unit kesehatan sekolah. Para siswi menyatakan tidak memiliki waktu memperhatikan atau merawat penampilan, tidak tahu cara merawat penampilan, tidak memiliki 
peralatan/perlengkapan, tidak nyaman, hingga tidak diizinkan orangtua atau guru. Sementara, penelitian menunjukkan siswa rentan mengalami stress ketika mendapati permasalahan kulit berupa jerawat baik dalam derajat ringan, sedang, dan berat (Alpajri, 2016).

Namun demikian, ada sebagian siswi menggunakan kosmetika dasar ke sekolah untuk melindungi wajah dari cuaca, agar lebih menarik, dan untuk menutupi kekurangan fisik. Dari hasil wawancara dengan siswi yang aktif dalam kegiatan ini, pemahaman tentang pentingnya memperhatikan dan merawat penampilan sejak dini diperoleh karena kerap menonton video tutorial di media sosial Youtube dari influencer di bidang kecantikan (beauty vlogger).

Pemberian pemahaman dan praktik menggunakan kosmetika menunjukkan siswa perlahan mulai memahami penggunaan kosmetika dasar atau sederhana. Hal ini ditunjukkan dari kuisioner di akhir kegiatan di mana tidak ada mahasiswa yang tidak mengetahui cara menggunakan kosmetika dasar. Menurut Parker, agar berhasil mendidik, seorang pendidik harus menggunakan waktu ekstra/tambahan untuk pengembangan dan kreativitas. Termasuk di dalamnya pelatihan melalui praktik, pembelajaran inovatif, dialogis dan melakukan evaluasi yang mendukung pembelajaran siswa (Parker, 2007).

\section{Kesimpulan}

\section{KESIMPULAN DAN SARAN}

Komunikasi artifaktual belum familiar/populer di telinga para siswi SMA. Remaja khususnya remaja putri perlu memahami komunikasi artifaktual melalui penampilan dan perawatan wajah. Pasalnya, remaja kerap gelisah, stress, tidak percaya diri ketika mendapati dirinya mengalami permasalahan pada kulit wajah. Sementara di sisi lain, belum ada upaya pencegahan yang dilakukan untuk mengatasi persoalan yang sering dihadapi tersebut.

Penggunaan kosmetika dasar dan perawatan sederhana merupakan salah satu cara membangun pesan artifaktual untuk membentuk citra tubuh, membangun jati diri, dan kepercayaan diri secara tidak berlebihan. Di tengah rutinitas kegiatan akademik dan non akademik, remaja perlu menyediakan waktu untuk merawat diri. Guru di sekolah juga diharapkan bisa mendukung para siswanya dalam menciptakan penampilan yang baik dan sewajarnya sebagai bekal menghadapi lingkungan profesional.

Ketika diberikan materi dengan bahasa yang sederhana, penyampaian interaktif, dan contoh nyata dalam kehidupan sehari-hari, para siswi mampu memahami konsep komunikasi artifaktual. Kegiatan pelatihan komunikasi artifaktual yang dilakukan dengan praktik terbukti mampu meningkatkan pemahaman para siswa.

\section{Saran}

Pelatihan komunikasi artifaktual disertai praktik perlu menyediakan waktu yang lebih longgar sehingga materi bisa disampaikan lebih leluasa. Dengan waktu yang lebih banyak maka praktik bisa dilakukan pada seluruh peserta. Selain itu, kegiatan ini fokus pada komunikasi artifaktual dalam hal penggunaan kosmetika dasar. Sementara masih ada obyek komunikasi artifaktual lainnya yang melekat pada manusia seperti penggunaan pakaian, perhiasan, rambut, pemilihan warna, dan wangi tubuh.

\section{Ucapan Terima Kasih}

Penulis mengucapkan terima kasih kepada Direktorat Penelitian dan Pengabdian Kepada Masyarakat Universitas Tarumanagara yang telah memberi dukungan finansial terhadap terselenggaranya pengabdian ini. 


\section{DAFTAR PUSTAKA}

Alpajri, A. 2016. Hubungan Tingkat Stres Dengan Tingkat Keparahan Akne. Fakultas Kedokteran, Universitas Muhammadiyah Surakarta, Sukoharjo, Jawa Tengah.

Oktiani, V. 2020. 10 Urutan Makeup Lengkap yang Benar Cocok untuk Pemula, https://wolipop.detik.com/makeup-and-skincare/d-4884679/10-urutan-makeup-lengkapyang-benar-cocok-untuk-pemula, diakses tgl 3 Juli 2020.

DeVito, J. A. 2013. The Interpersonal Communication Book Thirteenth Edition. Pearson Education: New Jersey.

Fatimah, E. 2008. Psikologi Perkembangan Peserta Didik. Pustaka Setia: Bandung.

Mulyana, D. 2013. Ilmu Komunikasi Suatu Pengantar. Remaja Rosdakarya: Bandung.

Nastiti, A. D., \& Purworini, D. 2018. Pembentukan Harga Diri: Analisis Presentasi Diri Pelajar SMA di Media Sosial. Jurnal Komunikasi. vol 10, hal 33-47.

Parker, J. 2007. Developing effective practice learning for tomorrow's social. Social Work Education. vol 26, hal 763-779.

Rakhmat, J. 2005. Psikologi Komunikasi Edisi Revisi. Remaja Rosdakarya: Bandung.

Sarwono, S. W. 2013. Pengantar Psikologi Umum. Raja Grafindo Persada: Depok.

Suryabrata, S. 2016. Psikologi Kepribadian. Raja Grafindo Persada: Jakarta. 